\title{
ANALIZA STATECZNOŚCI KONSTRUKCJI ZESPOLONEJ ,RURA-WYKŁADZINA ŚCIŚLE PASOWANA" NA PODSTAWIE WYTYCZNYCH DWA-A 143-2
}

\begin{abstract}
W artykule omówione zostaną dostępne na rynku rękawowe systemy renowacji sieci kanalizacji grawitacyjnej oraz możliwości ich zastosowania, zależne od stanu technicznego obiektu. Tematem wiodącym artykułu jest procedura doboru charakterystyk technicznych wykładziny przeprowadzana według wytycznych DWA-A 143-2. Podstawowym etapem projektowania jest dobór parametrów wytrzymałościowych, który po dokonaniu oceny stanu technicznego odcinka sieci, powinien gwarantować optymalizację ekonomiczną i konstrukcyjną proponowanego rozwiązania.
\end{abstract}

Słowa kluczowe: obliczenia statyczne, technologie bezwykopowe, renowacja, rehabilitacja, rurociągi

\section{Wprowadzenie}

Rozwój bezwykopowych technologii renowacji podziemnej infrastruktury technicznej, jaki obserwujemy na przestrzeni ostatnich lat, umożliwił prowadzenie na dużą skalę programów rewitalizacji sieci kanalizacyjnych. Tendencja ta zauważalna jest $\mathrm{w}$ wielu aglomeracjach miejskich, gdzie przeprowadzone zostały duże programy poprawy stanu technicznego podziemnej infrastruktury kanalizacyjnej.

W przypadku rurociągów grawitacyjnych, najczęściej stosowanymi technologiami bezwykopowymi są ściśle pasowane technologie rękawowe. Popularność tej grupy technik naprawczych, wynika z takich jej charakterystycznych cech, jak:

- szybkości wykonania renowacji,

- minimalizacji utrudnień komunikacyjnych,

- uzyskiwaniu dobrych parametrów statyczno-wytrzymałościowych,

- wysokiej odporności chemicznej stosowanych materiałów.

${ }^{1}$ Tomasz Abel, Politechnika Wrocławska, Katedra Mechaniki Budowli i Inżynierii Miejskiej, ul. Wybrzeże Wyspiańskiego 27, 50-370 Wrocław, tel. 07132032 37, tomasz.abel@pwr.edu.pl 
W metodach rękawowych stosowane są tkaniny techniczne, stanowiące szkielet powłoki naprawczej, tworzonej przy zastosowaniu do jej impregnacji różnego typu materiałów żywicznych, utwardzanych po zamontowaniu i właściwym ułożeniu rękawa w kanale. Metody rękawowe są powszechnie znane pod nazwą Cured in Place Pipe (CIPP), co potocznie oznacza ,rękaw formowany na miejscu". W metodach tych stosowane są wykładziny wykonane z materiału kompozytowego, składające się ze specjalnej włókniny syntetycznej lub tkaniny technicznej z włókien szklanych, o grubości od kilku do kilkudziesięciu milimetrów. Wykładziny impregnowane są żywicami poliestrowymi, epoksydowymi lub winyloestrowymi i utwardzane po właściwym ułożeniu rękawa w kanale. Od strony zewnętrznej wykładzina powleczona jest najczęściej folią z poliuretanu (PU), polietylenu (PE) lub polipropylenu (PP) [1].

W zależności od przewidzianej technologii montażu rękawa nasycanie żywicą może odbywać się u producenta lub na placu budowy. $\mathrm{Z}$ uwagi na niedokładności związane z procesem nasycenia (możliwość wystąpienia pęcherzyków powietrza w strukturze wykładziny), znacznie lepsze oraz zapewniające znacząco wyższą jakość wykonawstwa jest wykonanie impregnacji u producenta i dostarczenie przygotowanego rękawa na teren budowy.

$\mathrm{Na}$ etapie montażu nieutwardzona wykładzina jest podatna, co gwarantuje idealne dopasowanie do dowolnego kształtu przekroju poprzecznego kanału. Wykładziny typu CIPP mogą być zatem stosowane do renowacji przewodów o dowolnych przekrojach. Jedynym ograniczeniem wpływającym na problemy instalacji rękawa w kanałach o przekrojach innych niż kołowe mogą być braki sprzętowe. W szczególności chodzi o dostępność na rynku pneumatycznych korków zamykających kanał. Przekroje inne niż kołowe mogą wymagać zastosowania specjalnie do tego celu wykonanych elementów, co wpływa na koszty wykonania renowacji. Zakres średnic obecnie stosowanych wykładzin CIPP wynosi od $100 \mathrm{~mm}$ do około $3000 \mathrm{~mm}$. W związku ze stałym rozwojem technologii oraz sposobów wytwarzania materiałów nie są to wartości docelowe. Długość odcinka przeznaczonego do jednorazowej renowacji zależna jest od średnicy kanału i może dochodzić do kilkuset metrów przy małych średnicach. W przypadku dużych średnic, renowacji poddaje się zwykle odcinki kanału między kolejnymi studzienkami lub komorami, co jest technologicznie uzasadnione z uwagi na montaż urządzeń peryferyjnych, koniecznych do instalacji rękawa. Ograniczeniem, dotyczącym montażu rękawów, jest ich ciężar, szczególnie w przypadku dużych średnic i długich odcinków kanału [1].

Obecnie na polskim rynku technologii bezwykopowych stosowane są głównie trzy rodzaje wykładzin CIPP:

- wykładziny w postaci mat z włókien poliestrowych o strukturze filcowej, nasyconych żywicami poliestrowymi utwardzanymi termicznie,

- wykładziny w postaci mat z włókien poliestrowych o strukturze filcowej, nasyconych żywicami epoksydowymi utwardzanymi termicznie, 
- wykładziny w postaci tkaniny z włókien szklanych, nasyconej żywicami poliestrowymi (GRP UV) utwardzanymi promieniami UV.

Utwardzanie wykładzin z włókien poliestrowych odbywa się metodą termiczną, najczęściej przez podgrzanie wody wypełniającej kanał lub przepuszczanie gorącej pary pod ciśnieniem. Alternatywą jest stosowanie wykładziny z włókien szklanych, utwardzanej promieniami UV. Wykładziny te charakteryzują się znacznie wyższymi wartościami parametrów wytrzymałościowych i dzięki temu mogą być cieńsze niż rękawy poliestrowe, co wpływa na łatwość montażu oraz koszty.

Renowacja z zastosowaniem ściśle pasowanych wykładzin rękawowych wymaga dokładności, gdyż grupa przedmiotowych technologii jest bardzo podatna na różnego rodzaju błędy, które mogą zostać popełnione na poszczególnych etapach procesu realizacji zadania, począwszy od przyjęcia założeń projektowych a skończywszy na wykonawstwie. O uzyskanym efekcie końcowym decyduje kilka czynników, takich jak: metoda projektowania, zastosowane materiały oraz wykonawstwo [1].

Uzyskane po wykonaniu renowacji parametry powłoki wzmacniającej można sprawdzić przez wykonanie badań w ramach odbioru technicznego wykonanych prac. Podstawowymi badaniami odbiorowymi powinny być:

- wstępne sprawdzenie prawidłowości wykonania danego odcinka poddawanego renowacji, poprzez wykonanie inspekcji TV,

- sprawdzenie prawidłowości czyszczenia rurociągów przed przystąpieniem do montażu wykładziny,

- badanie jakości materiałów użytych do renowacji sieci, obejmujące w szczególności:

- sprawdzeniu dokumentów identyfikujących materiał,

- sprawdzenie stanu materiału,

- badanie szczelności kanału po renowacji,

- badania wytrzymałościowe pobranych próbek rękawa.

W związku z koniecznością stałej kontroli jakości wykonanych robót niezbędne jest wprowadzanie i przestrzeganie odpowiednich zapisów znajdujących się w dokumentacji projektowej, precyzujących zasady odbioru technicznego. Pamiętać należy jednak o tym, że z uwagi na reologiczne właściwości żywic, awarie utwardzonych powłok mogą się zdarzać po zakończeniu okresów gwarancyjnych. Renowacja $\mathrm{z}$ zastosowaniem technologii rękawowych powinna gwarantować przedłużenie żywotności przewodu o minimum 50 lat. W związku z powyższym inwestor powinien zadbać o przeprowadzenie pełnego zakresu badań odbiorowych, wykonanych przez niezależną jednostkę badawczą. Wszelkie prace naprawcze, związane ze źle wykonanym w kanale rękawem, są bardzo kosztowne i uciążliwe, a często prawie niemożliwe do przeprowadzenia. 


\section{Dobór parametrów projektowanego rozwiązania}

Realizowane na terenie całego kraju inwestycje pokazują, że zarówno w przypadku budowy nowych odcinków sieci podziemnych, jak i projektów renowacji istniejących sieci, etap projektowania, a w szczególności obliczenia statyczne, nie są wykonywane z zachowaniem koniecznych warunków brzegowych oraz założeń obliczeniowych. Potwierdzeniem nieprawidłowości założeń projektowych są, w przypadku niedowymiarowania konstrukcji, zdarzające się awarie, oraz zbyt duże, niepotrzebne koszty, jakie ponosi zamawiający w związku z przewymiarowaniem projektowanych konstrukcji, w tym rękawów CIPP.

W przypadku renowacji wszelkiego typu rurociągów szczególną uwagę zwracać należy na istniejące uszkodzenia, wykryte podczas inspekcji CCTV. $\mathrm{Z}$ uwagi na prostotę konstrukcji sieci podziemnych, tj. liniowość oraz stały przekrój monolityczny przekładający się na jednoprętowy ustrój statyczny - dla przekroju poprzecznego kanału bez uszkodzeń, diagnostyka podstawowych wad oraz nieprawidłowości stanowi nieskomplikowane zagadnienie inżynierskie [2]. Jeśli istniejący rurociąg wykazuje np. pęknięcia podłużne $\mathrm{w}$ przypadku rurociągów z rur sztywnych lub nadmierne ugięcia dla rurociągów z materiałów podatnych, to jest to jednoznaczna wskazówka statycznego przeciążenia. Powodem takich sytuacji mogą być następujące nieprawidłowości:

- błędnie przeprowadzone obliczenia statyczne,

- błędnie przyjęte wartości obciążeń zewnętrznych,

- nieodpowiedni materiał, z którego wykonano rury,

- nieprawidłowe wykonanie rurociągu,

- niedostateczne uszczelnienie,

- szerszy wykop niż przyjęto w obliczeniach statycznych,

- brak zbieżności pomiędzy obliczeniami statycznymi a wykonawstwem,

- zmiany założeń projektowych na etapie wykonawstwa,

- zmiana przyjętych warunków brzegowych już w trakcie eksploatacji obiektu,

- zmiana poziomu gruntu (wyższe pokrycie gruntem),

- prace ziemne w sąsiedztwie (ustał efekt silosu),

- zmiana poziomu wód gruntowych w wyniku działania czynników zewnętrznych.

\section{Analiza obliczeniowa}

W procesie obliczeniowym może się znaleźć wiele błędnych założeń prowadzących do uzyskania nieprawidłowego wyniku końcowego, niezgodnego z warunkami pracy konstrukcji, nieadekwatnego do występujących uszkodzeń [5].

W przypadku budowy sieci kanalizacyjnych oraz innych rurociągów podziemnych koniecznym jest wyznaczenie działających obciążeń, takich jak: 
- obciążenie gruntem i obciążenie użytkowe od taboru samochodowego (komunikacyjne),

- ciężar własny rurociągu,

- ciężar medium,

- ciśnienie wewnętrzne medium,

- ciśnienie wody gruntowej,

- inne obciążenia.

W związku z oddziaływaniem wielu składowych sumarycznego obciążenia (patrz rys. 1) koniecznym jest uwzględnienie różnych kombinacji obciążeń, ponieważ zaistnienie wszystkich obciążeń jednocześnie nie musi być najbardziej niekorzystnym wariantem. Zmieniające się warunki brzegowe mają bezpośredni wpływ na zmianę współczynnika bezpieczeństwa, co pokazano w tabeli 1.

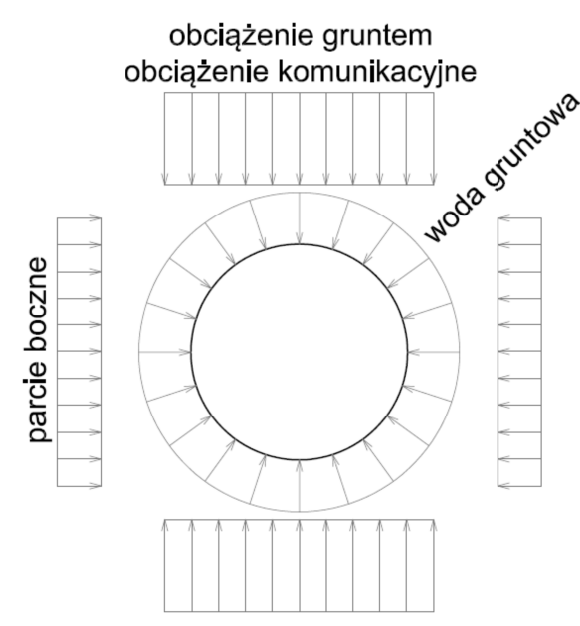

Rys. 1. Ogólny schemat statyczny przekroju poprzecznego kanału (na podstawie [5])

Fig. 1. General scheme for the static - channel cross section (based on [5])

Powyższy przykład pokazuje, że jeżeli zostaną zmienione wszystkie warunki brzegowe, współczynnik bezpieczeństwa zmaleje z 2,39 do 1,46. Tymczasem wymaganą bezpieczną wartością jest wartość równa 2,2. Oznacza to, że jeśli zmieni się tylko jeden warunek brzegowy, współczynnik bezpieczeństwa będzie mniejszy niż 2,2 i warunek bezpieczeństwa nie będzie spełniony.

Z tego powodu już przy nowych budowlach należy zwrócić uwagę na obliczenia statyczne odpowiadające rzeczywistym warunkom brzegowym i obciążeniom. Właściwe określenie warunków brzegowych, m.in. w zakresie statyki, jest zadaniem inwestora lub administratora sieci i powinno zostać zawarte w przygotowanym na potrzeby realizacji zadania programie funkcjonalno-uz̈ytkowym. $\mathrm{W}$ trakcie prowadzenia procesu inwestycyjnego, na który składają się dwa pod- 
stawowe etapy, tj.: etap projektowy oraz etap wykonawczy, inwestor, definiując wymagania, powinien na każdym etapie prac sprawdzać zgodność realizacji z przyjętymi założeniami. Na etapie wykonania projektu sprawdzeniu powinny podlegać warunki określone przez Inwestora, a na etapie wykonawstwa założenia przyjęte $\mathrm{w}$ projekcie.

Tabela 1. Zmiana wartości współczynnika bezpieczeństwa - przykład (na podstawie [5])

Table 1. Changing the value of the safety factor - example (based on [5])

\begin{tabular}{|c|c|c|c|c|c|}
\hline L.P. & $\begin{array}{l}\text { Warunek } \\
\text { brzegowy }\end{array}$ & Wartość & $\begin{array}{l}\text { Współczyn- } \\
\text { nik bezp. }\end{array}$ & $\begin{array}{c}\text { Zmiana } \\
\text { warunku } \\
\text { brzegowego }\end{array}$ & $\begin{array}{c}\text { Nowy } \\
\text { współczynnik } \\
\text { bezpieczeń- } \\
\text { stwa }\end{array}$ \\
\hline 1 & $\begin{array}{c}\text { Warunki } \\
\text { zasypania } \\
\text { wykopu/ } \\
\text { posadowienia } \\
\text { przewodu }\end{array}$ & $\begin{array}{c}\text { A4/B4 } \\
\text { (zgodnie } \\
\text { z DWA-A } \\
\text { 143-2) }\end{array}$ & \multirow{5}{*}{2,39} & $\begin{array}{c}\text { A1/B1 } \\
\text { (zgodnie } \\
\text { z DWA-A } \\
143-2 \text { ) }\end{array}$ & 1,66 \\
\hline 2 & Kąt podparcia & 120 & & 60 & 2,08 \\
\hline 3 & $\begin{array}{c}\text { Szerokość } \\
\text { wykopu } \\
\text { na wysokości skle- } \\
\text { pienia rury }\end{array}$ & $1,50 \mathrm{~m}$ & & $3,00 \mathrm{~m}$ & 1,46 \\
\hline 4 & $\begin{array}{l}\text { Poziom wód } \\
\text { gruntowych }\end{array}$ & $3,00 \mathrm{~m}$ & & brak & 1,87 \\
\hline 5 & $\begin{array}{l}\text { Brak ciśnienia } \\
\text { wewnętrznego }\end{array}$ & ---- & & $2,00 \mathrm{~m}$ & 1,78 \\
\hline
\end{tabular}

W przypadku braku określenia wstępnych warunków brzegowych realizacji zadania oraz braku koordynacji i nadzoru nad prowadzonymi pracami projektowymi zachodzi niebezpieczeństwo, że wyjściowe dane użyte do obliczeń będą odbiegały od wartości rzeczywistych, co wpłynie na nieprawidłowy dobór parametrów materiałowych, a w konsekwencji skutkować będzie groźbą awarii lub katastrofy obiektu.

Jeśli przewidywane jest oddziaływanie budowanego obiektu na istniejący, przyległy obiekt, np. w przypadku układania nowych równoległych lub krzyżujących się kanałów, albo też możliwe jest obniżenie się poziomu wód gruntowych, należy sprawdzić statykę istniejącego rurociągu. W pracach instalacyjnych szczególnie istotne jest dokonanie sprawdzeń dla obiektów liniowych usytuowanych powyżej poziomu remontowanego rurociągu, jeśli w efekcie końco- 
wym spodziewamy się podwyższenia poziomu wód gruntowych i zaistnienia zjawiska wyporu hydrostatycznego, które wcześniej nie miało miejsca.

\section{Statyka kanałów wzmacnianych wykładzinami ściśle pasowanymi}

Instalacja wykładziny ściśle pasowanej wewnątrz uszkodzonego kanału umożliwia odtworzenie szczelności oraz pierwotnej nośności rurociągu, na utratę których wpłynęły uszkodzenia, które pojawiły się w kanale. Przykłady uszkodzeń pokazano na rysunku 2. Należy pamiętać o tym, że wbudowanie ściśle pasowanego rękawa nie podwyższy nośności powyżej pierwotnej nośności rury, jak również nie umożliwi usunięcia deformacji i nie wpłynie na poprawę spadków kanału.

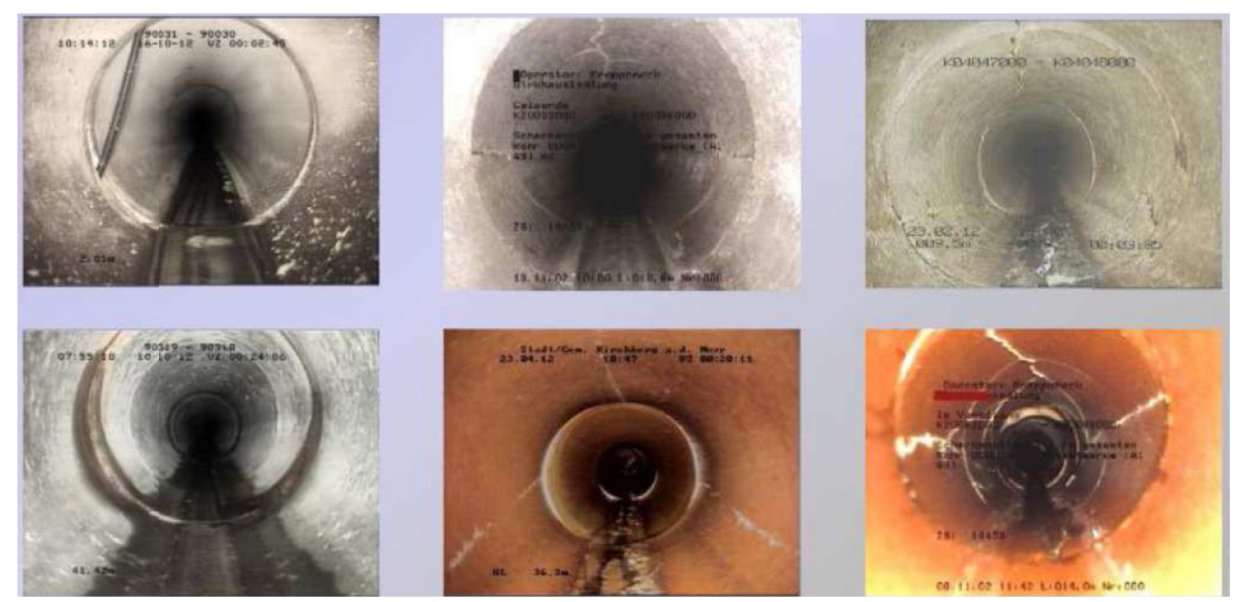

Rys. 2. Przykłady stanu technicznego kanałów (na podstawie [5])

Fig. 2. Examples of the technical state of the channel (based on [5])

W przypadku stosowania technologii ściśle pasowanych zdeformowany przekrój kanału pozostaje bez zmian. W konsekwencji oznacza to, że obliczenia statyczne rękawa muszą być dobrane do aktualnej sytuacji. Rękaw, pod względem statycznym, musi odpowiadać pierwotnej sytuacji i ewentualnie przejąć część obciążeń od gruntu i obciążeń zmiennych, których układ ,istniejąca rura - grunt" nie będzie w stanie przenieść w wyniku pojawiających i propagujących uszkodzeń. Po wykonaniu wewnętrznej powłoki układ rura - wykładzina należy traktować jako konstrukcję zespoloną.

W obliczeniach statycznych wykładzin stosowana jest powszechnie instrukcja ATV-M 127P-2 [3], która ukazała się po raz pierwszy w styczniu 2000 i stała się uznanym dokumentem regulującym przedmiotowe zagadnienia. W lipcu 2010 przedmiotowa instrukcja została opublikowana w wydaniu popra- 
wionym. W efekcie wprowadzenia Eurokodu i udoskonalenia procedur montażowych $\mathrm{z}$ zastosowaniem rękawów ściśle pasowanych, konieczne stały się zmiany i aktualizacje wytycznych. Aktualizacje opublikowane zostały w wytycznych DWA-A 143-2 [6] w listopadzie 2012, zaś od lipca 2015 instrukcja DWA-A 143-2 zastąpiła dotychczasową instrukcję ATV-M 127P-2. W wytycznych DWA-A 143-2 zdefiniowano następująco stany techniczne rur poddanych renowacji:

- I stan techniczny - wystarczająca wytrzymałość starej rury na zginanie i rozciąganie,

- II stan techniczny - istniejąca rura spękana wzdłuż, w otaczającym gruncie został zaburzony stan równowagi,

- III stan techniczny - przesunięcia gruntu oraz deformacje kanału spowodowane obciążeniami komunikacyjnymi przy niewystarczającym przykryciu warstwą gruntu, osunięcia gruntu, wahania poziomu wód gruntowych (system stale niestabilny).

\section{Rodzaje faz pracy występujących podczas bezwykopowej renowacji sieci}

W obliczeniach statycznych rurociągów poddawanych renowacji z zastosowaniem technologii rękawowych oraz technologii reliningu (,rura w rurę") należy dokonać sprawdzeń warunków w dwóch fazach pracy takiego układu:

Faza montażu:

- sprawdzenie deformacji przy obciążeniu przestrzeni pierścieniowej,

- sprawdzenie odkształcenia,

- sprawdzenie naprężenia i wgniecenia podczas wciągania rur (dla klasycznego reliningu).

Faza użtkowania:

- sprawdzenie stabilności w przypadku zewnętrznego ciśnienia wody gruntowej,

- sprawdzenie naprężenia,

- sprawdzenie odkształcenia,

- sprawdzenie zmęczenia materiału (obciążenie komunikacyjne, np. pod torami kolejowymi).

W przypadku obliczeń statycznych rękawów ściśle pasowanych nie wykonuje się testów w fazie montażu. Należy przeprowadzić jedynie testy w fazie użytkowania. W tym celu należy poddać działaniu obciążenia największego z oczekiwanych w całym planowanym okresie użytkowania (zwykle 50 lat) i dla wartości długoterminowych obliczać parametry materiałowe.

Dawniej, wartość współczynnika bezpieczeństwa ustalano na podstawie obciążeń obliczeniowych i parametrów materiałowych, a jego wartość musiała być większa od wartości wymaganej. Obecnie, przy pomocy częściowych współczynników bezpieczeństwa, parametry materiałowe są zmniejszane a wartości obciążeń obliczeniowych zwiększane. 
Na etapie określania stanu technicznego odcinka kanału należy zdefiniować oraz określić pod względem jakościowym i ilościowym występujące usterki. Raport o stanie technicznym powinien stanowić podstawę do dalszych prac, w szczególności do przeprowadzenia obliczeń statycznych.

\section{Algorytm obliczeniowy}

Zastosowanie technologii rękawa utwardzanego na miejscu stanowi optymalne rozwiązanie dla rurociągów pozostających w drugim stanie technicznym a więc takich, które wykazują podłużne spękania ale stan gruntu wokół nich nie został zmieniony. $\mathrm{W}$ takim przypadku renowacja $\mathrm{z}$ zastosowaniem wewnętrznej ściśle pasowanej wykładziny jest również uzasadniona ekonomicznie $\mathbb{z}$ uwagi na równowagę między kosztami a uzyskanymi efektami.

W takim przypadku, wstępnie ustalane jest krytyczne parcie wody gruntowej, przy którym system staje się niestabilny (rękaw zostaje wgniatany do środ$\mathrm{ka}$ ), a następnie dokonuje się analizy porównawczej z obliczeniowym ciśnieniem wody gruntowej. Jednocześnie, przy zastosowaniu częściowego współczynnika bezpieczeństwa, zmniejszany jest moduł sprężystości E, a wartość obliczeniowego ciśnienia wody gruntowej zwiększana.

Algorytm ten umożliwia przeprowadzenie obliczeń stabilności układu niewielkim nakładem pracy, bez konieczności stosowania metod komputerowych. Umożliwia także stosunkowo proste sprawdzenie poprawności przyjętych założeń. Ponadto, uzyskane wyniki pozwalają na optymalizację w zakresie doboru grubości ścianki rękawa, co jest najistotniejszym parametrem ekonomicznym, decydującym o kosztach realizacji inwestycji, które to z kolei są czynnikiem decydującym dla inwestora w zakresie wykonania zaplanowanych zadań. Algorytm obliczeniowy pokazano schematycznie na rys. 3 .



Rys. 3. Algorytm obliczeniowy (na podstawie [5])

Fig. 3. Calculation algorithm (based on [5]) 
W toku obliczeniowym wykorzystane są następujące wartości liczbowe:

- $\kappa \mathrm{V}$-współczynnik zmniejszający uwzględniający deformację początkową zgodnie z rys. 6 ,

- $\kappa \mathrm{Gr}, \mathrm{v}$ - współczynnik zmniejszający uwzględniający owalizację zgodnie z rys. 5 ,

- $\kappa S$-współczynnik zmniejszający uwzględniający szczelinę pierścieniową zgodnie z rys. 4 ,

- $\mathrm{rL}$ - średni promień wykładziny,

- tL - grubość ścianki wykładziny,

- EL - moduł sprężystości wykładziny,

- $\gamma \mathrm{M}$ - częściowy współczynnik zmniejszający wg DWA-A 143-2,

- $\mu$ - współczynnik Poissona dla materiału wykładziny.

Współczynniki zmniejszające, uwzględniające lokalną deformację początkową w postaci szczeliny pierścieniowej, owalizacji oraz lokalnej deformacji, wyznaczane są na podstawie wykresów pokazanych na rys. 4, 5, 6 .

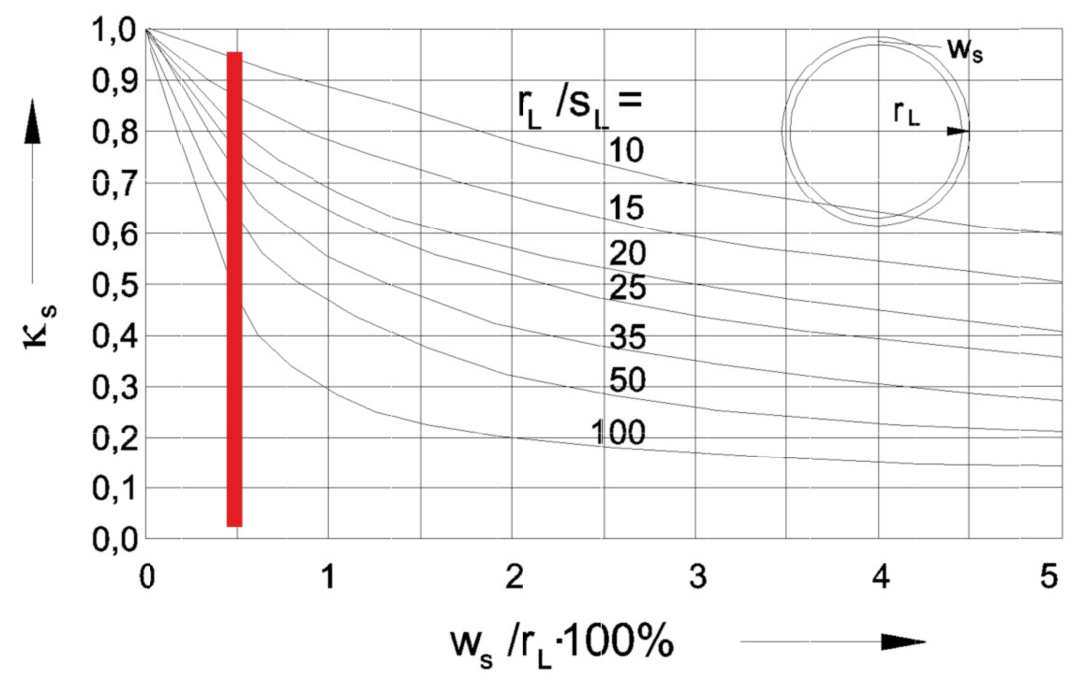

Rys. 4. Współczynnik zmniejszający dla uwzględnienia lokalnej deformacji początkowej $\mathrm{w}$ postaci szczeliny pierścieniowej (na podstawie [5]): $\mathrm{w}_{\mathrm{s}}$ - wielkość prześwitu pomiędzy wykładziną a istniejącym przewodem, $\mathrm{s}_{\mathrm{L}}-$ grubość ścianki wykładziny, $\mathrm{r}_{\mathrm{L}}$ - średni promień wykładziny

Fig. 4. Derating factor to take into account local deformations in the original form of the annular gap (based on [5]) 


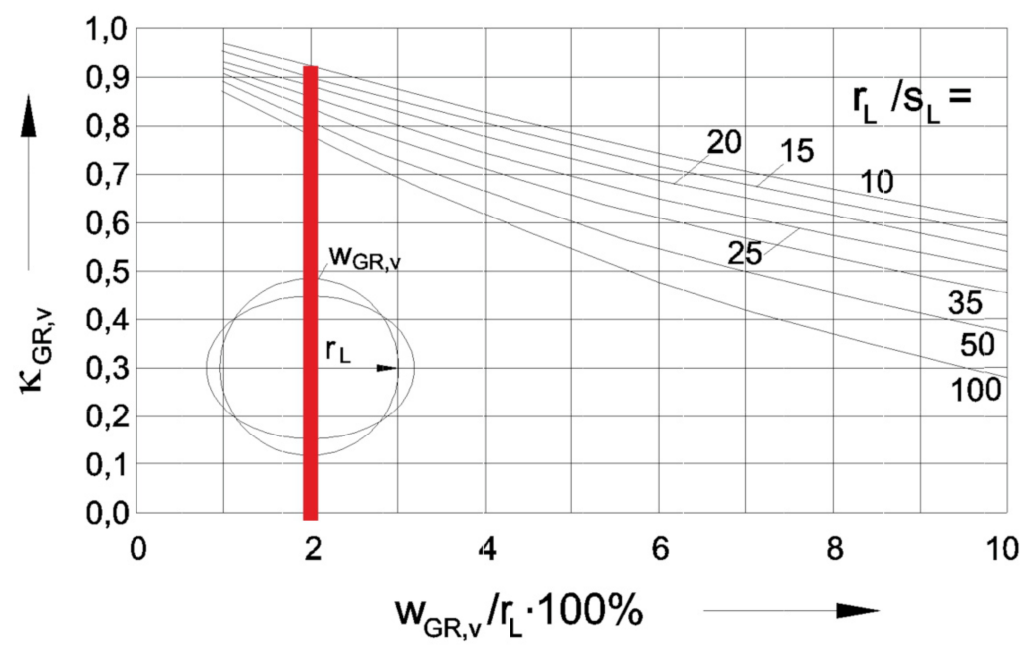

Rys. 5. Współczynnik zmniejszający dla uwzględnienia lokalnej deformacji początkowej na przegubach - owalizacji (na podstawie [5]): $\mathrm{w}_{\mathrm{GR}, v}$ - ugięcie przekroju istniejącego przewodu na przegubach, $\mathrm{s}_{\mathrm{L}}$ - grubość ścianki wykładziny, $\mathrm{r}_{\mathrm{L}}$ - średni promień wykładziny

Fig. 5. Derating factor to take into account the local deformation of the initial wrists - ovalization (based on [5])

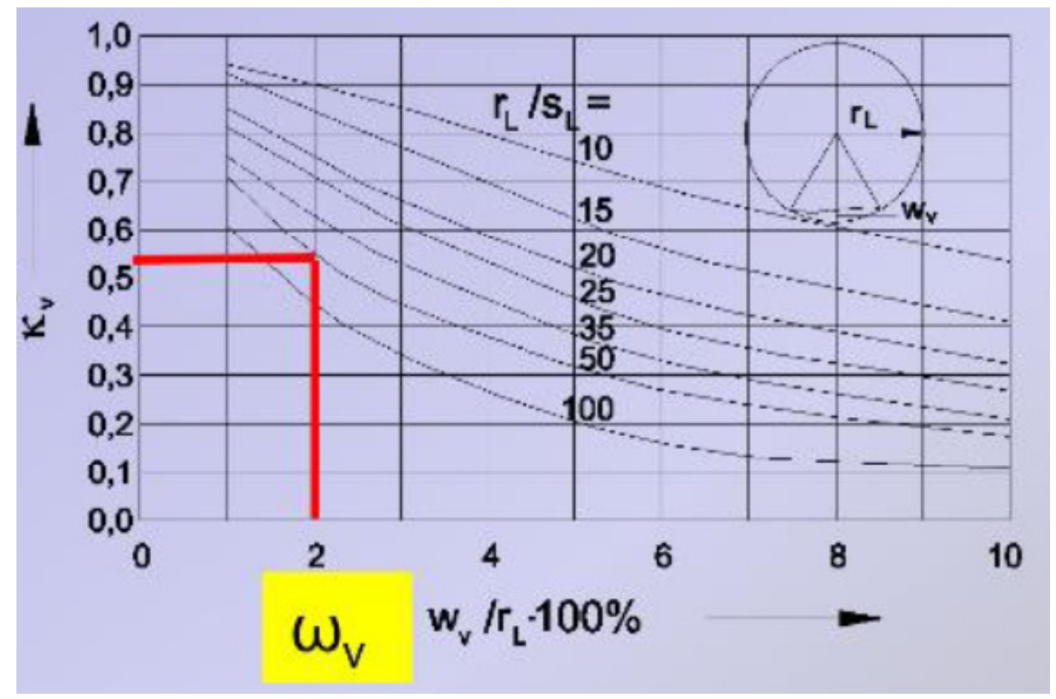

Rys. 6. Współczynnik zmniejszający przy uwzględnieniu lokalnej deformacji początkowej (na podstawie [5]): $\mathrm{w}_{\mathrm{v}}$ - głębokość lokalnej deformacji wykładziny, $\mathrm{s}_{\mathrm{L}}$ - grubość ścianki wykładziny, $\mathrm{r}_{\mathrm{L}}$ - średni promień wykładziny

Fig. 6. Derating factor to take into account the local initial deformation (based on [5]) 


\section{Tabelaryczne wartości sztywności obwodowej rur a warunki realizacji zadania}

Wielu inwestorów, odpowiedzialnych za procedury przetargowe, zasadniczo jest przekonanych, że stosując tabelaryczne wartości sztywności zamieszczone w DWA-M 144-3 [4] i innych wytycznych lub katalogach produktów, nie trzeba sprawdzać warunków stateczności w analizowanej konstrukcji. Założenie to jest równie fałszywe, jak zdanie, że ponieważ dla rur istnieją regularne lub typowe wartości sztywności, w trakcie projektowania kanału nie jest konieczne dokonanie obliczeń statycznych.

Typowe (katalogowe) sztywności obwodowe służą jedynie obliczaniu warunków brzegowych dla konkretnego przypadku. Jeśli warunki brzegowe są inne, warunek stateczności typowej nie ma zastosowania. Ponieważ każdy istniejący obiekt znajduje się w określonym, koniecznym do zdefiniowania, stanie technicznym, należy dobór parametrów statyczno-wytrzymałościowych oraz warunków brzegowych przeprowadzać indywidualnie dla każdego przypadku.

Wiedza o typowych parametrach wytrzymałościowych stosowanego materiału nie zdejmuje $\mathrm{z}$ inwestora odpowiedzialności za zapewnienie stabilności rękawa ściśle pasowanego. Tabele typowej sztywności [4] mają za podstawę II stan techniczny rury istniejącej i minimalne wartości przyjmowanych nieprawidłowości zgodnie z DWA-A 143-2 [6] (dawniej ATV-M 127P-2 [3]), a więc lokalną deformację początkową od $2 \%$, owalizację od $3 \%$ i szczelinę pierścieniową od $0,5 \%$ każdorazowo w stosunku do promienia rękawa. Powyżej przytoczone warunki brzegowe, jak pokazuje doświadczenie autora, w takiej właśnie korelacji, praktycznie nie występują, co za tym idzie tracą ważność założenia katalogowe, umożliwiające tabelaryczny dobór parametrów technicznych.

Poniżej przytoczono przykład, który pokazuje jak istotny wpływ na dobór grubości wykładziny ma błędne oszacowanie warunków brzegowych.

Przy minimalnym ciśnieniu zewnętrznym równym $1,5 \mathrm{~m}$ słupa wody nad dnem rury oraz przy założeniu odpowiedniej grupy materiałowej istniejącej rury wymagana grubość rękawa ściśle pasowanego przy średnicy DN 500 wynosi zgodnie z tabelami stateczności typowej w DWA-M 144-3 [4] 3,3 mm. Należy pamiętać o tym, że chodzi tu o grubość ściany zespalającej, bez folii i warstw żywicy, a nie o grubość ściany wbudowanej. Zamieszczona tabela 2 pokazuje, jak zmienia się wymagana grubość ściany zespalającej przy zmienionych warunkach brzegowych. Kolumny 2 i 3 określają wymagane grubości ściany zespalającej, jakie można odczytać w tabelach typowej stateczności każdorazowo dla danego poziomu wód gruntowych, przy przyjęciu wartości minimalnych uszkodzeń. W kolumnie 4 ustalona jest wymagana grubość zespolenia zgodnie z DWA-A 143-2 [6] dla większych uszkodzeń. 
Tabela 2. Zmiana grubości wykładziny w zależności od warunków brzegowych.

Table 2. Changing the thickness of the liner depending on the boundary conditions.

\begin{tabular}{|c|c|c|c|}
\hline & $\begin{array}{c}\text { Według } \\
\text { wytycznych }\end{array}$ & $\begin{array}{c}\text { Według } \\
\text { wytycznych }\end{array}$ & $\begin{array}{c}\text { Wartość } \\
\text { obliczeniowa }\end{array}$ \\
\hline Lokalna deformacja początkowa & $2 \% \mathrm{z} \mathrm{r}_{\mathrm{L}}$ & $2 \% \mathrm{z} \mathrm{r}_{\mathrm{L}}$ & $2 \% \mathrm{z} \mathrm{r}_{\mathrm{L}}$ \\
\hline Owalizacja & $2 \% \mathrm{z} \mathrm{r}_{\mathrm{L}}$ & $2 \% \mathrm{z} \mathrm{r}_{\mathrm{L}}$ & $2 \% \mathrm{z} \mathrm{r}_{\mathrm{L}}$ \\
\hline Szczelina pierścieniowa & $2 \% \mathrm{z} \mathrm{r}_{\mathrm{L}}$ & $2 \% \mathrm{z} \mathrm{r}_{\mathrm{L}}$ & $2 \% \mathrm{z} \mathrm{r}_{\mathrm{L}}$ \\
\hline Poziom wód gruntowych & $1,5 \mathrm{~m}$ & $2,5 \mathrm{~m}$ & $2,5 \mathrm{~m}$ \\
\hline Wymagana grubość rękawa & $3,3 \mathrm{~mm}$ & $3,8 \mathrm{~mm}$ & $4,9 \mathrm{~mm}$ \\
\hline
\end{tabular}

Powyższy przykład pokazuje, że w przypadku niedoszacowania uszkodzeń (porównaj kolumnę 3 i 4), przy zastosowaniu wartości tabelarycznych rękaw byłby za cienki o 1,1 mm. Dlatego w fazie planowania i określania warunków przetargu należy przykładać jak największą uwagę do tego, by dokładnie ustalić warunki brzegowe. Uzyskanie pełnowartościowej informacji na temat warunków brzegowych umożliwia jedynie dokładna inwentaryzacja obiektu i dokonanie oceny jego stanu technicznego. Niewłaściwy dobór parametrów rękawa, w tym przypadku jego grubości mającej bezpośredni wpływ na sztywność, może powodować przeciążenie statyczne, ponadnormatywną deformację i w konsekwencji awarię.

\section{Podsumowanie}

Poprawność statycznych obliczeń rękawa ściśle pasowanego ma istotne znaczenie z punktu widzenia kosztów planowanych prac renowacyjnych. Posługiwanie się katalogowymi wartościami typowej sztywności obwodowej, bez szczegółowej analizy rzeczywistych warunków brzegowych, może prowadzić do błędnych rezultatów. Wartości tabelaryczne odnoszą się do typowych, standardowych warunków brzegowych i nie są miarodajne przy większych, nietypowych uszkodzeniach oraz dla III stanu technicznego. W takich przypadkach należy zawsze dokonać indywidualnych obliczeń statycznych, po to by dobrany rękaw osiągnął oczekiwaną długość okresu użytkowania. Ponadto właściwy dobór parametrów wytrzymałościowych projektowanego rękawa wpływa na optymalizację poniesionych przez inwestora kosztów, a potencjalnym wykonawcom zapewnia bezpieczeństwo w zakresie gwarancji na wykonane prace. 


\title{
Literatura
}

[1] Kolonko A., Kujawski W., Przybyła B., Roszkowski A., Rybarski S.: Podstawy bezwykopowej rehabilitacji technicznej przewodów wodociągowych i kanalizacyjnych na terenach zurbanizowanych, Izba Gospodarcza Wodociągi Polskie, Bydgoszcz 2011.

[2] Madryas C., Przybyła B., Wysocki L.: Badania i ocena stanu technicznego przewodów kanalizacyjnych, Dolnośląskie Wydawnictwo Edukacyjne, Wrocław 2010.

[3] Materiały Pomocnicze ATV-DVWK - M127P: część 2: Obliczenia statycznowytrzymałościowe dla rehabilitacji technicznej przewodów kanalizacyjnych przez wprowadzenie linerów lub metodą montażową, styczeń 2000.

[4] Materiały Pomocnicze DWA-M 144-3: Dodatkowe Techniczne Warunki Umowy (DTWU) dla renowacji systemów odprowadzania wody poza budynkami, część 3: Renowacja metodą rękawa elastycznego (rękaw elastyczny utwardzany na miejscu) w kanałach ściekowych, listopad 2011.

[5] Wacker R.: Statische berechnung von schlauchlinern nach DWA-A 143-2, Konference SOVAK CR, Roztoky u Prahy 2016.

[6] Wytyczne DWA-A 143-2: Renowacja systemów odprowadzania wody na zewnątrz budynków, część 3: Rękawy utwardzane na miejscu, maj 2014.

\section{STABILITY ANALYSIS OF COMPOSITE PIPE-CLOSE FIT LINING IN ACCORDANCE WITH THE GUIDELINES DWA-A 143-2}

\begin{abstract}
S u m m a r y
The paper will deal with those prevailing on the Polish market of trenchless pipe rehabilitation technologies. Discussed will be no-dig renovation technologies available on the market of gravity sewers and their applicability depending on the technical condition of the renovated section of the network. The main issue raised is the process of selection of lining strength carried out in accordance with the guidelines DWA-A 143-2. The main stage of the design process is to analyze the stability of lining inside the pipe. The condition of properly selected static parameters is properly carried out assessment of the technical condition as a result, the adoption of appropriate boundary conditions. Renovation should ensure optimization of economic and construction of the proposed solution.
\end{abstract}

Keywords: static analysis, no-dig technologies, renovations, rehabilitations, pipelines

DOI: $10.7862 / \mathrm{rb} .2016 .147$

Przestano do redakcji: 01.05.2016 $r$.

Przyjęto do druku: 28.06.2016 r. 